\title{
Molecular detection of Kudoa septempunctata (Myxozoa: Multivalvulida) in sea water and marine invertebrates
}

\author{
Alagesan Paari ${ }^{1,2,4}$, Chan-Hyeok Jeon ${ }^{1,2,5}$, Hye-Sung Choi ${ }^{3,6}$, Sung-Hee Jung ${ }^{3}$ and Jeong-Ho Kim ${ }^{1,7^{*}}$
}

\begin{abstract}
The exportation of cultured olive flounder (Paralichthys olivaceus) in Korea has been recently decreasing due to the infections with a myxozoan parasite Kudoa septempunctata, and there is a strong demand for strict food safety management because the food poisoning associated with consumption of raw olive flounder harbouring K. septempunctata has been frequently reported in Japan. The life cycle and infection dynamics of K. septempunctata in aquatic environment are currently unknown, which hamper establishment of effective control methods. We investigated sea water and marine invertebrates collected from olive flounder farms for detecting $K$. septempunctata by DNA-based analysis, to elucidate infection dynamics of $K$. septempunctata in aquaculture farms. In addition, live marine polychaetes were collected and maintained in well plates to find any possible actinosporean state of $K$. septempunctata. The level of $K$. septempunctata DNA in rearing water fluctuated during the sampling period but the DNA was not detected in summer (June-July in farm A and August in farm B). K. septempunctata DNA was also detected in the polychaetes Naineris laevigata intestinal samples, showing decreased pattern of 40 to $0 \%$. No actinosporean stage of $K$. septempunctata was observed in the polychaetes by microscopy. The absence of $K$. septempunctata DNA in rearing water of fish farm and the polychaetes $N$. laevigata intestinal samples during late spring and early summer indicate that the infection may not occur during this period. N. laevigata was suspected as the possible alternate invertebrate host of $K$. septempunctata, but the actinosporean stage was not found by well plate method and further studies will be necessary. This research provides important baseline information for understanding the infection dynamics of K. septempunctata in olive flounder farms and further establishment of control strategies.
\end{abstract}

Keywords: Kudoa septempunctata, Myxozoa, Olive flounder, Paralichthys olivaceus, Naineris laevigata

\section{Background}

Myxozoans belong to the group of metazoan parasites of fish and act as a cause for several outbreaks in both fresh water and marine fish (Canning and Okamura 2003). Disease transmission by these myxozoan parasites can often have disastrous economic impact in aquaculture industries, although most of them are known to have insignificant or negligible effect in fish (Yokoyama et al. 2012). The genus Kudoa comprises more than 70 species reported from a broad range of fish host (Miller and

\footnotetext{
*Correspondence: jhkim70@gwnu.ac.kr

'Department of Marine Bioscience, Gangneung-Wonju National University, Gangneung, Gangwon 25457, South Korea

${ }^{7}$ Department of Marine Bioscience, Gangneung-Wonju National University, Gangneung, Gangwon 210-702, South Korea

Full list of author information is available at the end of the article
}

Adlard 2012). Most of the species are histozoic which develop symptoms of macroscopic whitish cyst or cause post-mortem myoliquefaction (Shirakashi et al. 2012). However, some Kudoa species do not cause any of the symptoms mentioned above and Kudoa septempunctata, a newly found myxosporean found in olive flounder (Paralichthys olivaceus) is probably the most well-known example of them (Yokoyama et al. 2004; Matsukane et al. 2010) .

Since 2011, food poisoning due to ingestion of farmed olive flounders in Japan has been reported (Kawai et al. 2012). Epidemiological studies have revealed that this outbreak is associated with the presence of $K$. septempunctata in the causative foods (Kawai et al. 2012) and the food-borne outbreaks associated with consumption 
of raw olive flounder harbouring $K$. septempunctata are becoming a prominent public health concern in Japan. As the customs of consuming raw fish is spreading, the occurrence of this food-borne disease is predicted to increase (Harada et al. 2012). Although there have been outbreaks in Japan since 2011, the question of olive flounder in Korea acting as a host of K. septempunctata remains unanswered (Iwashita et al. 2013). Considering the commercial value of olive flounder and the public health concern, it is urgently needed to solve the negative impact of this parasite on public health and food safety, but almost nothing is known about its transmission biology, infection dynamics in aquatic environment.

Myxozoan parasites have been believed to be transmitted from fish to fish until Wolf and Markiw (1984) demonstrated that freshwater oligochaete was essential for the transmission of Myxobolus cerebralis and since then, many studies have confirmed that some myxozoans undergo two-host life cycle (Lom and Dykova 2006; Markussen et al. 2015). Currently, more than 30 freshwater myxozoans are known to have two-host life cycles (Yokoyoma et al. 2012), but only 7 marine myxozoans are found to have marine invertebrates to complete their life cycles (Karlsbakk and Køie 2012; Køie et al. 2004, 2007, 2008, 2013; Rangel et al. 2015), and neither life cycle nor invertebrate alternate hosts have been elucidated in kudoid myxozoans.

Environmental water analysis is indispensable for investigating epidemiology of myxozoan infections because fish myxozoans occur in aquatic environment and transmission between two different hosts also occur in environmental water. Many studies revealed that the disease transmission occurs via water in endemic area and appropriate water treatments were effective for the management of several myxozoan infections (Cobcroft and Battaglene 2013; Nehring et al. 2003; Yanagida et al. 2006). Thus, the environmental water analysis would be the first step to clarify infection dynamics and develop further effective management strategy for K. septempunctata infection. As knowledge about the infection dynamics of this parasite is scarce, we carried out a monthly inspection of water samples to study the occurrence pattern of $K$. septempunctata in aquatic environment by molecular analysis. We also investigated the prevalence of $K$. septempunctata in marine polychaetes collected around the farms using both of well plate method described by Yokoyama et al. (1991) and molecular analysis, to speculate the possible life cycle of $K$. septempunctata.

\section{Methods}

Water sampling and DNA extraction

Water samples were directly collected from the inlet pumping units from two aquaculture farms where $K$. septempunctata infection occurs (farm A, B). Sampling was conducted on a monthly basis during May and November 2014 and approximately 21 of water was collected in each sampling. Water samples were filtered through a fresh nitrocellulose membrane filter (5 $\mu \mathrm{m}$ pore size; ADVENTEC, Japan) using a suction pump (DOA-P704-AA, GAST, USA), and the membrane filter were placed in an individual micro centrifuge tube and stored at $-20{ }^{\circ} \mathrm{C}$ until DNA extraction.

Acetone dissolution method was used for extracting DNA from the filter samples (Hallett et al. 2012). The membrane filter in microcentrifuge tube was air dried and dissolved by adding $2 \mathrm{ml}$ of acetone (Cica reagent, Japan). The completely solubilized filter components by repeated vortexing were then centrifuged at $3000 \mathrm{~g}$ for $15 \mathrm{~min}$, and the supernatant was discarded. This step was repeated twice to ensure complete dissolution of filtrate particles from the dissolved materials. To the dissolved filtrate samples, $1 \mathrm{ml}$ of $95 \%$ ethanol was added and thoroughly mixed. The suspended pellet after centrifugation was then air dried and used directly for DNA extraction.

DNA was extracted by using a QIAamp DNA Mini Kit (QIAGEN, USA) according to the manufacturer's instructions with slight modifications. Briefly, $180 \mu \mathrm{l}$ of tissue lysis buffer (Buffer AE, QIAGEN, USA) was added to the air-dried pellet sample, and then $20 \mu \mathrm{l}$ of Proteinase K (QIAGEN, USA) was added. Following overnight incubation, wash buffers (Buffer AW1, AW2, QIAGEN, USA) were added and eluted using elution buffer (Buffer AE, QIAGEN, USA). Extracted DNA was stored at $-20{ }^{\circ} \mathrm{C}$ until used for PCR detection.

\section{PCR and real-time PCR for detecting K. septempunctata in rearing water}

PCR was carried out for detecting $K$. septempunctata in water samples using the following set of primer sets: $K s$-GTGTGTGATCAGACTTGATATG; $K s$ R-AAGCCA AAACTGCTGGCCATTT [25]. $0.5 \mu \mathrm{M}$ of forward and reverse primer, $1 \mu \mathrm{l}$ of template DNA was added to the PCR premix tube (Bioneer, Korea) and the total volume was made to $20 \mu \mathrm{l}$ using ultra-pure distilled water (Invitrogen, USA). PCR cycling parameters followed the protocols of Grabner et al. (2012) with some minor modifications. PCR cycling parameters were an initial denaturation at $95{ }^{\circ} \mathrm{C}$ for $4 \mathrm{~min}$, followed by 35 cycles at $95{ }^{\circ} \mathrm{C}$ for $35 \mathrm{~s}, 56{ }^{\circ} \mathrm{C}$ for $30 \mathrm{~s}$ and $72{ }^{\circ} \mathrm{C}$ for $30 \mathrm{~s}$ and ended with a final extension at $72{ }^{\circ} \mathrm{C}$ for $7 \mathrm{~min}$.

Real-time PCR was carried out using the following sequence of primers and probe; F-CATGGGATTAGCCC GGTTTA; R-ACTCTCCCCAAAGCCGAAA; P-(FAM)TCCAGGTTGGGCCCTCAGTGAAAA (Kawai et al. 2012). Real-time PCR was carried out in a 0.2-ml PCR strip tube containing $2 \times$ Premix Ex Taq (Takara, Japan) 
$10 \mu \mathrm{l}$, primer $(0.4 \mathrm{uM}$, Bioneer, Korea), probe $(0.25 \mu \mathrm{M}$, Bioneer, Korea), ROX II reference dye (Takara, Japan), $4 \mu \mathrm{l}$ template DNA using ABI 7500 Fast Real-time PCR system (Applied Biosystems, USA). Cycling parameters were preheating at $95{ }^{\circ} \mathrm{C}$ for $10 \mathrm{~min}$, followed by 45 cycles at $95{ }^{\circ} \mathrm{C}$ for $15 \mathrm{~s}, 60{ }^{\circ} \mathrm{C}$ for $1 \mathrm{~min}$ and the analyses were conducted twice.

\section{Collection of marine invertebrates and species identification}

Marine invertebrates from the sediments of fish tanks and coastal areas near fish farms were collected to investigate the prevalence of $K$. septempunctata infection. For collecting invertebrate samples, mud was collected from approximately $0.5 \mathrm{~m}$ depth from outflow waterway of the same fish farms where the water samples were collected and transferred to laboratory. Sediments were sieved through a mesh $(0.5 \mathrm{~mm})$ to separate marine polychaetes within a day of collection of sediment. Live polychaetes were collected, washed with sterile sea water several times, and then maintained in a 12-well plate at $15{ }^{\circ} \mathrm{C}$, for observing the possible actinosporean stages of K. septempunctata.

For collecting invertebrate samples from coastal areas, quadrats and dredging devices were used by trained divers to obtain marine invertebrates near the olive flounder farms. Subsamples of invertebrate samples collected from the gravel materials were washed with sterile sea water and were fixed in $70 \%$ ethanol for taxonomic identification and molecular detection.

Species identification for all the collected invertebrate samples was conducted by morphological observations or PCR amplification of the mitochondrial cytochrome c oxidase subunit I ( $\mathrm{mt} \mathrm{COI}$ ) gene as described by Maturana et al. (2011). For molecular identification, PCR primers targeting the partial mt COI gene described by Folmer et al. (1994) were used. LCO1490: 5'-GGTCAACAAATCATAAAGATATTGG-3'; HC02198: 5' -TAAACTTCA GGGTGACCAAAAAATCA-3' DNA was extracted from the polychaete samples using the QIAamp DNA Mini Kit with the protocol described previously, and PCR was carried out in a $20 \mu \mathrm{l}$ of reaction volume consisted of $10 \mu \mathrm{l}$ of PCR premix (Bioneer, Korea), $1 \mu \mathrm{l}$ of template DNA, $1 \mu \mathrm{l}$ of $10 \mu \mathrm{M}$ of each primers and $17 \mu \mathrm{l}$ of double-distilled deionized water. PCR cycling parameters were an initial denaturation phase at $94{ }^{\circ} \mathrm{C}$ for $1 \mathrm{~min}$, followed by 35 cycles at $94{ }^{\circ} \mathrm{C}$ for $30 \mathrm{~s}, 49{ }^{\circ} \mathrm{C}$ for $55 \mathrm{~s}$, and $72{ }^{\circ} \mathrm{C}$ for $90 \mathrm{~s}$, and a final extension at $72{ }^{\circ} \mathrm{C}$ for $10 \mathrm{~min}$. Following amplification, PCR products were analysed in a $2 \%$ agarose gels and stained with ethidium bromide. PCR products of the expected size were purified using PCR gel purification kit (Bioneer, Korea). Gel-purified PCR amplicons were sequenced in both directions utilizing the same primers used for initial amplification. The obtained sequences of mt COI gene were aligned and identified based on the percentage identity of nucleotide sequences previously registered in NCBI.

\section{Microscopic detection of $K$. septempunctata from polychaetes}

Live polychaetes collected from the outflow waterway sediments of fish tank were observed for the occurrence of actinospores by well plate method (Yokoyama et al. 1991). Briefly, collected polychaetes were washed with sterile sea water several times, individually placed in a 12-well plate and observed microscopically using an inverted microscope (Leica, Germany) every day to find if the possible $K$. septempunctata actinospores were released. Sea water in the wells was replaced in a 2-day interval. Squash preparations were also made from the isolated polychaetes samples at every 2 days interval for observation of the actinosporeans; several posterior segments of the intestinal region of polychaetes were squashed between the slide and cover slip, fixed with methanol, stained with Giemsa solutions and examined using a light microscope (Leica, Germany).

Invertebrate samples collected around the coastal regions were not maintained in well plates but immediately processed for microscopic analysis using squash preparations and for PCR detection using the same methodology mentioned above.

\section{PCR and real-time PCR detection of $K$. septempunctata in marine invertebrates}

Polychaetes collected from the outflow waterway sediments of fish tank were examined for K. septempunctata by PCR and real-time PCR. DNA was extracted from the whole body of polychaetes using QIAamp DNA Mini Kit (QIAGEN, USA) following manufacturer's instructions. The PCR and real-time PCR primers and amplification conditions used in this analysis are mentioned above. Prevalence of $K$. septempunctata was calculated as the proportion of infected invertebrate host in the whole number of studied host. PCR for detecting $K$. septempunctata was also conducted for invertebrate samples collected from the coastal regions using the same protocol mentioned previously.

\section{Results}

Detection of $K$. septempuncta in rearing water samples by PCR and real-time PCR

During the sampling period, positive signals for $K$. septempunctata were not detected in any of the water samples from two farms by PCR (Table 1). The standard curve for real-time PCR was derived from 10-fold serial dilutions of different plasmid DNA concentrations ranging from $1 \times 10^{8}$ to $1 \times 10^{1}$ copies $/ \mu \mathrm{l}$, as described by Kawai et al. (2012). The assays were linear with $R^{2}$ values 
Table 1 Detection of $K$. septempunctata DNA in rearing water samples from fish farms by molecular methods

\begin{tabular}{|c|c|c|c|c|c|c|}
\hline \multirow[t]{3}{*}{ Sampling date } & \multirow{2}{*}{\multicolumn{2}{|c|}{ PCR }} & \multicolumn{4}{|c|}{ Real-time PCR } \\
\hline & & & \multicolumn{2}{|l|}{ Ct value } & \multicolumn{2}{|l|}{ rDNA copy number } \\
\hline & Farm A & Farm B & Farm A & Farm B & Farm A & Farm B \\
\hline 2014. May. & - & - & $40.9,41.1$ & $40.1,43.0$ & $9.0,7.7$ & $16.3,1.9$ \\
\hline 2014. Jun. & - & - & $N D, N D$ & $42.2,40.4$ & $\mathrm{ND}, \mathrm{ND}$ & $3.4,13.1$ \\
\hline 2014. Jul. & - & - & $N D, N D$ & $36.1,38.3$ & $N D, N D$ & $3.2 \times 10^{2}, 62.5$ \\
\hline 2014. Aug. & - & - & $42.2, \mathrm{ND}$ & ND, ND & $3.5, \mathrm{ND}$ & ND, ND \\
\hline 2014. Sept. & - & - & $41.4,39.3$ & 40.7, ND & 6.2. 29.7 & $10.4, N D$ \\
\hline 2014. Oct. & - & - & $36.3,34.5$ & $37.0,37.9$ & $2.8 \times 10^{2}, 1.1 \times 10^{3}$ & $1.6 \times 10^{2}, 87.5$ \\
\hline 2014. Nov. & - & - & $40.0,39.5$ & $39.3,39.8$ & $18.3,26.2$ & $29.7,20.4$ \\
\hline
\end{tabular}

of 0.993 (Fig. 1). Relative K. septempunctata DNA concentration was calculated based on the $\mathrm{Ct}$ value. The amount of $K$. septempunctata DNA was inversely proportional to the $\mathrm{Ct}$ value obtained in this study, and the $\mathrm{Ct}$ value of the highest standard $\left(10^{8}\right.$ copies/ $\left.\mu \mathrm{l}\right)$ was 14.8 and the lowest standard $\left(10^{1}\right.$ copies $\left./ \mu \mathrm{l}\right)$ was 37.1 .

The level of rDNA copy number for all of the water samples fluctuated during the sampling period in both of the farms. The $\mathrm{Ct}$ value ranged from 36.3-42.2 in farm A and 36.1-42.2 in farm B (Table 1). The highest rDNA copy number $\left(1.1 \times 10^{3}\right)$ of $K$. septempunctata in Farm A was recorded in October. In Farm B, the highest rDNA copy number was recorded $3.2 \times 10^{2}$ in August. Interestingly, K. septempuctata DNA was not detectable during June-July in farm A and August in farm B.

\section{Incidence of $K$. septempunctata in marine invertebrate samples collected from fish farms}

Microscopic observation of the marine polychaetes collected was conducted on a daily basis until they die. The live polychaetes survived for 7 to 10 days in the well plate; however, no actinosporean release was observed from them during the incubation period. The squashed slide

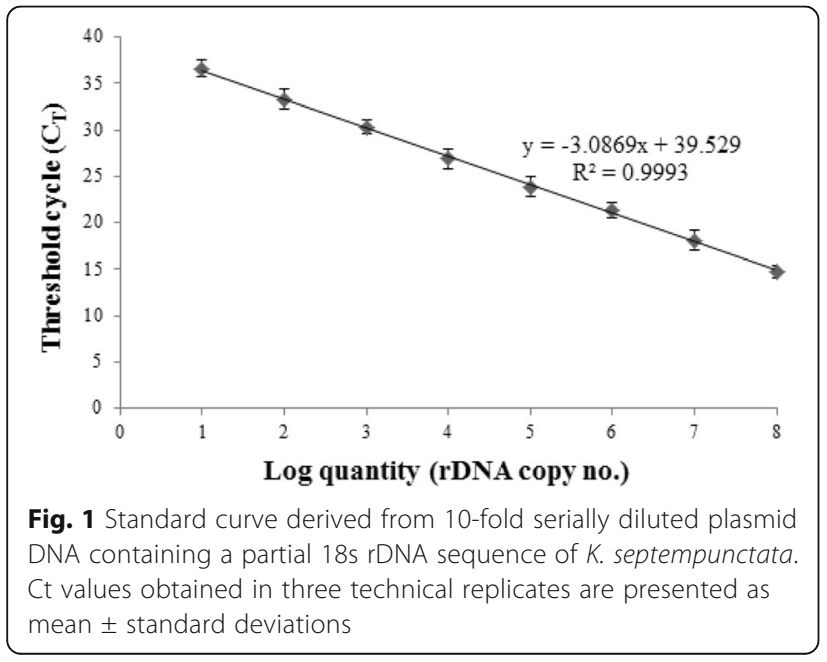

specimens were made with the intestinal segments of randomly selected polychaetes, and microscopic observation was also conducted after Giesma and eosin staining, but any actinosporean-like stage of $K$. septempunctata was not found (data not shown).

All of the polychaetes were identified using PCR. Primers targeting mt COI gene amplified a PCR product of size $710 \mathrm{bp}$, and the amplified sequences represent the species Naineris laevigata (Polychaeta, Orbiniidae) with 99.0\% homology (data not shown).

K. septempunctata DNA was detected in polychaetes by PCR and real-time PCR during the sampling period. PCR detection of $K$. septempunctata in polychaete intestinal sample showed the mean prevalence of 9.5\% (55/578) (Table 2). The highest prevalence of $K$. septempunctata in polychaetes by PCR (40.0\%) was recorded in May of 2014, then, gradually decreased to $0 \%$ in August.

Quantitative analysis of $K$. septempunctata DNA in polychaetes samples revealed the parasitic DNA was detectable only in May and June. The Ct value was 38.9-41.4 in May and 35.5-38.3 in June. Although the incidence of PCR-

Table 2 PCR and real-time PCR results for detecting $K$. septempunctata in orbiniid polychaete $N$. laevigata isolated from outflow waterway of fish tank

\begin{tabular}{|c|c|c|c|}
\hline & \multirow{2}{*}{$\begin{array}{l}\text { PCR Positive samples/ } \\
\text { tested samples (\%) }\end{array}$} & \multicolumn{2}{|c|}{ Real-time PCR } \\
\hline & & Ct value & $\begin{array}{l}\text { rDNA copy } \\
\text { number/ body } \\
\text { weight }(\mathrm{g})\end{array}$ \\
\hline May & $36 / 90(40.0 \%)$ & $38.9-41.4$ & $2.5 \times 10^{3}-1.6 \times 10^{3}$ \\
\hline June & $14 / 62(22.6 \%)$ & $35.5-38-3$ & $2.0 \times 10^{3}-2.1 \times 10^{4}$ \\
\hline July & $5 / 126(4.0 \%)$ & nd & nd \\
\hline August & $0 / 84$ & nd & nd \\
\hline September & $0 / 82$ & nd & nd \\
\hline October & $0 / 62$ & nd & nd \\
\hline \multirow[t]{2}{*}{ November } & $0 / 72$ & nd & nd \\
\hline & $55 / 578(9.5 \%)$ & & \\
\hline
\end{tabular}


positive samples was higher in May, the rDNA copy number was higher in June (Table 2).

\section{Incidence of $K$. septempunctata in marine invertebrate samples collected from coastal area}

Invertebrate samples collected during May to November around the coastal area near olive flounder farm were identified by microscopic observation at the lowest taxon level, and the results are summarized in Table 3. All of the collected samples were negative for K. septempunctata by PCR and not detected by real-time PCR.

\section{Discussion}

Outbreaks due to consumption of raw olive flounder harbouring $K$. septempunctata have been reported in Japan since 2011 (Kawai et al. 2012; Harada et al. 2012).

Table 3 Detection of $K$. septempunctata in marine invertebrates collected from coastal waters in this study

\begin{tabular}{|c|c|c|c|}
\hline Family name & Species name & $\begin{array}{l}\text { Number of individuals } \\
\text { examined }\end{array}$ & PCR \\
\hline Arabellidae & Arabella iricola & 4 & - \\
\hline Chrysopetalidae & $\begin{array}{l}\text { Chrysopetalum } \\
\text { occidentale }\end{array}$ & 1 & - \\
\hline Cirratulidae & Dodecaceria laddi & 1 & - \\
\hline \multirow[t]{2}{*}{ Eunicidae } & Eunice antennata & 6 & - \\
\hline & Lysidice collaris & 2 & - \\
\hline Euphrosinidae & Euphrosine superba & 3 & - \\
\hline \multirow[t]{4}{*}{ Nereidae } & Nereis multignatha & 4 & - \\
\hline & Nereis neoneanthes & 1 & - \\
\hline & Perinereis cultrifera & 5 & - \\
\hline & $\begin{array}{l}\text { Platynereis } \\
\text { bicanaliculata }\end{array}$ & 5 & - \\
\hline Opheliidae & Polyophalmus pictus & 3 & - \\
\hline Orbiniidae & Naineris laevigata & 5 & - \\
\hline \multirow[t]{2}{*}{ Phyllodocidae } & Eulalia virdis & 1 & - \\
\hline & Notophyllum sp. & 2 & - \\
\hline \multirow[t]{3}{*}{ Polynoidae } & $\begin{array}{l}\text { Halosydna } \\
\text { brevisetosa }\end{array}$ & 19 & - \\
\hline & $\begin{array}{l}\text { Harmothoe } \\
\text { imbricata }\end{array}$ & 3 & - \\
\hline & Lepidonotus sp. & 1 & - \\
\hline \multirow[t]{2}{*}{ Serpulidae } & Hydroides exalata & 2 & - \\
\hline & $\begin{array}{l}\text { Spirobranchus } \\
\text { tetraceros }\end{array}$ & 2 & - \\
\hline \multirow[t]{4}{*}{ Syllidae } & Unidentified 1 & 11 & - \\
\hline & Unidentified 2 & 4 & - \\
\hline & Trypanosyllis zebra & 2 & - \\
\hline & $\begin{array}{l}\text { Typosyllis } \\
\text { ehlersioides }\end{array}$ & 2 & - \\
\hline Terebellidae & Unidentified & 3 & - \\
\hline
\end{tabular}

However, information on the transmission biology of $K$. septempunctata is still lacking as we are not aware of the alternate polychaete host to complete its life cycle or the transmission dynamics of $K$. septempunctata in marine environment. In this study, we analysed rearing water samples from fish farms on a monthly basis for the presence of $K$. septempunctata by molecular methods.

Since the discovery of the myxozoan life cycle by Wolf and Markiw (1984), a lot of fresh water myxozoans have been known to use freshwater oligochaetes as alternate invertebrate hosts (Yokoyama et al. 2012). For marine myxozoans, however, polychaetes have been suggested as the best candidates for the alternative invertebrate hosts; seven marine myxozoan life cycles have been elucidated at present time, and all of them are known to use polychaetes as alternative invertebrate hosts (Karlsbakk and Køie 2012; Køie et al. 2004, 2007, 2008, 2013; Rangel et al. 2009), except for Ortholinea auratae using marine oligochaete as marine invertebrate host (Rangel et al. 2015). Thus, we exclusively sampled marine invertebrates from the sediment of outflow waterway of fish tank and around the fish farms, then investigated them by microscopic observation and molecular analysis, to find the possible invertebrate hosts they use for transmission. Our investigations on myxospore infection were restricted for few months due to adverse climate conditions.

Parasite density in aquatic environment is an important factor affecting the level of myxozoan outbreaks (Ray et al. 2012) because the transmission of actinospores to teleost hosts occurs in aquatic environment. Real-time PCR has successfully detected the actinospores to measure parasite density in freshwater environment (Hallet and Bartholomew 2009; Hallett et al. 2012; True et al. 2009) but less frequently in marine environment. Alma-Bermejo et al. (2013) and Ishimaru et al. (2014) developed real-time PCR assay for detecting marine myxosporeans, Ceratomyxa puntazzi and Kudoa yasunagai in environmental sea water, respectively. They found the seasonal changes in parasitic density and mentioned that this may reflect the infection dynamics of marine myxozoans. In a similar manner, $K$. septempunctata DNA was detected both in water samples of two farms examined in this study. Overall $\mathrm{Ct}$ value was 36.3-42.2 in farm $\mathrm{A}$ and 36.1-43.0 in farm B, corresponding 3.5 to $2.8 \times 10^{2}$ copies of $K$. septempunctata $18 \mathrm{~s}$ rDNA from 21 water samples in farm $A$ and 3.0 to $3.2 \times 10^{2}$ copies in farm $B$, respectively (Table 1 ). These values are lower than those of $K$. yasunagai (Ishimaru et al. 2014) but higher than those of C. puntazzi (Alma-Bermejo et al. 2013). These differences are thought to be due to many factors including different infection dynamics between the parasites and their hosts, different aquaculture systems, many physical and chemical factors in the aquatic environments, as suggested by Ishimaru et al. (2014). In 
particular, a flow-through system pumping seawater directly from the open sea makes more difficult to understand the infection dynamics of $K$. septempunctata in olive flounder farms as because it has been suggested that the actinosporean stages are generally fragile and easy to be destroyed by strong water flow (Kerans and Zale 2002; Hoz Franco and Budy 2004; Hallet and Bartholomew 2007). Nevertheless, considering the sea water volume flowing into the fish tanks, the parasite density calculated in this study cannot be negligible and should be considered for elucidating infection dynamics of $K$. septempunctata in olive flounder farms.

The level of $K$. septempunctata DNA in rearing waters fluctuated during the experimental period, but $K$. septempuctata DNA was not detected in June-July (farm A) or August (farm B). Similar results were obtained by Ishimaru et al. (2014) with K. yasunagai and AlamaBermejo et al. (2013) with C. punctzaaii, suggesting the changes in parasite density in the water may be related to the water temperature. But it is not clear if the parasite DNA detected from water in this study is originated from actinospores from invertebrate hosts or from myxospores from fish hosts, which is also indicated as the major shortcoming of their study by the authors mentioned above. In addition, our data have some limitations because we analysed water samples only for a half year. Seasonality in the prevalence has been reported in many myxosporean infections (Al-Qahtani et al. 2015; Abdel-Baki et al. 2015), thus sentinel fish exposure to water from the endemic area throughout the year and discovery of actinospores with subsequent quantification of them in seawater are thought to be necessary, to prove the parasite DNA in seawater came from actinosporean stage of $K$. septempunctata. Recently, Yokoyama et al. (2015) described that the $K$. septempunctata predominantly invade juvenile olive flounder in July. In our study, K. septempunctata DNA in rearing water was not detected during June and July or in August, which is also indicating the infection may occur during summer season and can be helpful for avoiding $K$. septempunctata infection of olive flounder.

All of the live polychaetes from fish farm sediments were identified as Naineris laevigata (Polychaeta, Orbiniidae) by PCR amplification of $\mathrm{mt}$ COI gene and maintained in 12well plates for approximately 2 weeks, but no actinosporean stage were observed. Freshwater actinospores from oligochaetes have been successfully observed by well plate method (Yokoyama et al. 1991, 2012). However, we could not find any actinospores released from $N$. laevigata maintained in well plates in this study. Most of the actinospores from marine polychaetes have been observed either by collecting coelomic fluid of marine polychaetes with syringe needles or squash preparations (Køie et al. 2008; Rangel et al. 2009, 2011) and our study was the first trial to observe the release of actinospores from marine polychaetes by well plate method. Rangel et al. (2011) mentioned that the wellplate method may not be suitable for relatively big marine polychaetes. Otherwise, different mechanisms may work for the release of the actinospores from the invertebrate hosts; Køie (2002) mentioned that the actinospores are released via the gonopores of polychaetes, while Rangel et al. (2009) described that the actinospores are released together with the gametes by the rupture of the host's body wall. If this is the case, it will be necessary to exclusively make squash preparation or histological sections to observe possible actinosporean stages of $K$. septempunctata.

PCR could successfully detect $K$. septempunctata DNA in polychaetes in this study. The percentage of PCR positive individuals was the highest (40.0\%) in May, then gradually decreased during the experimental periods and maintained 0\% after August of 2014. Seasonal prevalence of actinospores in invertebrate hosts has been conducted in several experiments, but the seasonal variation patterns were different depending on the species examined (Rangel et al. 2009, 2011). These are thought to reflect the seasonality of vertebrate host life cycle or invertebrate host life cycle for at least some myxozoans. In case of $N$. laevigata in this study, seasonal pattern of PCRpositive rate was also observed. However, this should be carefully interpreted because PCR can detect both of mature and developmental stages of actinospores. In general, the prevalence of actinosporean infection in polychaetes is estimated by microscopic observation and known to be very low (Rangel et al. 2009, 2011). Thus, it would be helpful to detect any seasonal patterns in prevalence of actinosporean infection in polychaetes hosts by molecular method, but successful microscopic observation should be accompanied, which is also indispensable to make a clear conclusion whether $N$. laevigata is the alternate host of $K$. septempunctata.

\section{Conclusions}

Myxozoan infections in wild and farmed fish is becoming increasingly important as marine aquaculture expands to meet the resource demands and some of them actually cause economic loss in aquaculture industry by causing considerable mortality or losing market value of them. $K$. septempunctata does not belong to any of two types mentioned above because it does not cause any negative effect on host but may affect human beings. Thus, effective control methods for $K$. septempunctata infection in olive flounder are urgently needed. Based on the knowledge of the transmission biology, several methods have been suggested for controlling myxozoan infections and some of them have been proved to be effective. The information obtained in this study is thought to be helpful for establishing strategies to avoid K. septempunctata infection in olive flounder farms. 


\section{Abbreviations}

Ct: Threshold cycle; mt COI: Mitochondrial cytochrome c oxidase subunit 1; PCR: Polymerase chain reaction

\section{Acknowledgements}

We thank Jong-Goo Choi for his help during the experiments.

\section{Funding}

This work was supported by grants from the National Institute of Fisheries Science (R2016065).

\section{Author's contributions}

JHK conceived and designed the experiments. JHK and AP prepared the manuscript. AP and CHJ carried out sample collections and analyses. JHK, AP, $\mathrm{HSC}, \mathrm{SHJ}$, and $\mathrm{CHJ}$ interpreted the results. All authors read and approved the final manuscript.

\section{Ethics approval and consent to participate}

Not applicable.

\section{Consent for publication}

Not applicable.

\section{Competing interests}

The authors declare that they have no competing interests.

\section{Publisher's Note}

Springer Nature remains neutral with regard to jurisdictional claims in published maps and institutional affiliations.

\section{Author details}

'Department of Marine Bioscience, Gangneung-Wonju National University, Gangneung, Gangwon 25457, South Korea. ${ }^{2}$ East Coast Life Science Institute, Gangneung-Wonju National University, Gangneung, Gangwon 25457, South Korea. ${ }^{3}$ Pathology Division, National Institute of Fisheries Science (NIFS), Busan 46041, South Korea. ${ }^{4}$ Present address: Department of Life science, Christ University, Bengaluru, Karnataka, India. ${ }^{5}$ Present address: East Sea Life Resources Center, Korea Fisheries Resources Agency, 36340, Uljin, South Korea. ${ }^{6}$ Present address: Inland Aquaculture Research Center, NIFS, Changwon 51688, South Korea. ${ }^{7}$ Department of Marine Bioscience, Gangneung-Wonju National University, Gangneung, Gangwon 210-702, South Korea.

\section{Received: 8 May 2017 Accepted: 20 July 2017}

\section{Published online: 02 August 2017}

\section{References}

Abdel-Baki AA, Mansour L, Al-Qahtani HA, Al-Omar SY, Al-Quraishy S. Morphology, seasonality and phylogenetic relationships of Ceratomyxa husseini n. sp. from the gall-bladder of Cephalopholis hemistiktos (Rüppell) (Perciformes: Serranidae) in the Arabian Gulf of Saudi Arabia. Syst Parasitol. 2015;91:91-9.

Alama-Bermejo G, Sima R, Raga JA, Holzer AS. Understanding myxozoan infection dynamics in the sea: seasonality and transmission of Ceratomyxa puntazzi. Int J Parasitol. 2013;43:771-80.

Al-Qahtani HA, Mansour L, Al-Quraishy S, Abdel-Baki AS. Morphology, phylogeny and seasonal prevalence of Ceratomyxa arabica n. sp. (Myxozoa: Myxosporea) infecting the gallbladder of Acanthopagrus bifasciatus (Pisces: Sparidae) from the Arabian Gulf, Saudi Arabia. Parasitol Res. 2015;114:465-671.

Canning EU, Okamura B. Biodiversity and evolution of the myxozoa. Adv Parasitol. 2003;56:43-131.

Cobcroft JM, Battaglene SC. Ultraviolet irradiation is an effective alternative to ozonation as a sea water treatment to prevent Kudoa neurophila (Myxozoa: Myxosporea) infection of striped trumpeter Latris lineata (Forster). J Fish Dis. 2013;36:57-65

Folmer O, Black M, Hoeh W, Lutz R, Vrijenhoek R. DNA primers for amplification of mitochondrial cytochrome $\mathrm{C}$ oxidase subunit I from diverse metazoan invertebrates. Mol Mar Biol Biotechnol. 1994;3:294-9.

Grabner DS, Yokoyama H, Shirakashi S, Kinami R. Diagnostic PCR assays to detect and differentiate Kudoa septempunctata, K. thyrsites and K. lateolabracis (Myxozoa, Multivalvulida) in muscle tissue of olive flounder (Paralichthys olivaceus). Aquaculture. 2012;338:36-40.
Hallet SL, Bartholomew JL. Development and application of a duplex qPCR for river water samples to monitor the myxozoan parasite Parvicapsula minibicornis. Dis Aquat Org. 2009;86:36-50.

Hallet SL, Bartholomew JL. Effects of water flow on the infection dynamics of Myxobolus cerebralis. Parasitology. 2007;135:371-84.

Hallett SL, Ray RA, Hurst CN, Buckles GR, Atkinson SD, Bartholomew JL. Density of the waterborne parasite Ceratomyxa shasta and its biological effects on salmon. Appl Environ Microbiol. 2012;78:3724-31.

Harada T, Kawai T, Jinnai M, Ohnishi T, Sugita-Konishi Y, Kumeda Y. Detection of Kudoa septempunctata $18 \mathrm{~S}$ ribosomal DNA in patient fecal samples from novel food-borne outbreaks caused by consumption of raw olive flounder (Paralichthy solivaceus). J Clin Microbiol. 2012;50:2964-8.

Hoz Franco E, Budy P. Linking environmental heterogeneity to the distribution and prevalence of Myxobolus cerebralis: a comparison across sites in a Northern Utah water shed. Trans Am Fish Soc. 2004;133:1176-89.

Ishimaru K, Matsuura T, Tsunemoto K, Shirakashi S. Seasonal monitoring of Kudoa yasunagai from sea water and aquaculture water using quantitative PCR. Dis Aquat Org. 2014;108:45-52.

Iwashita Y, Kamijo Y, Nakahashi S, Shindo A, Yokoyama K, Yamamoto A, Omori Y, Ishikura K, Fujioka M, Hatada T, Takeda T, Maruyama K, Imai H. Food poisoning associated with Kudoa septempunctata. J. Emerg. Med. 2013; 44: 943-945.

Karlsbakk E, Køie M. The marine myxosporean Sigmomyxa sphaerica (Thélohan, 1895) gen. n., comb. n. (syn. Myxidium sphaericum) from garfish (Belone belone (L.)) uses the polychaete Nereis pelagica L. as invertebrate host. Parasitol. Res. 2012;110:211-218.

Kawai T, Sekizuka T, Yahata Y, Kuroda M, Kumeda Y, lijima Y, Kamata Y, SugitaKonishi Y, Ohnishi T. Identification of Kudoa septempunctata as the causative agent of novel food poisoning outbreaks in Japan by consumption of Paralichthys olivaceus in raw fish. Clin. Infect. Dis. 2012;54:1046-1052.

Kerans BL, Zale AV. The ecology of Myxobolus cerebralis. In Whirling Disease: Reviews and Current Topics (ed. Bartholomew, J. L. and Wilson, J. C.) American Fisheries Society Symposium. 29, Bethesda, Maryland, USA. 2002. p. 145-166.

Køie M. Spirorchid and serpulid polychaetes are candidates as invertebrate hosts for Myxozoa. Folia Parasitol. 2002:49:160-162

Køie M. Whipps CM, Kent ML. Ellipsomyxa gobii (Myxozoa: Ceratomyxidae) in the common goby Pomatoschistus microps (Teleostei: Gobiidae) uses Nereis spp. (Annelida: Polychaeta) as invertebrate hosts. Folia Parasitol. 2004;51:14-18.

Køie M, Karlsbakk E, Nylund A. A new genus Gadimyxa with three new species (Myxozoa, Parvicapsulidae) parasitic in marine fish (Gadidae) and the two host life cycle of Gadimyxa atlantica n. sp. J. Parasitol. 2007;93: 1459-1467

Køie M, Karlsbakk E, Nylund A. The marine herring myxozoan Ceratomyxa auerbachi (Myxozoa: Ceratomyxidae) uses Chone infundibuliformis (Annelida: Polychaeta: Sabellidae) as invertebrate host. Folia Parasitol. 2008:55:100-104

Køie M, Karlsbakk E, Einen ACB, Nylund A. A parvicapsulid (Myxozoa) infecting Sprattus sprattus and Clupea harengus (Clupeidae) in the Northeast Atlantic uses Hydroides norvegicus (Serpulidae) as invertebrate host. Folia Parasitol. 2013;60:149-154

Lom J, Dykova I. Myxozoan genera: definition and notes on taxonomy, life-cycle terminology and pathogenic species. Folia Parasitol. 2006;53:1-36.

Markussen T, Agusti C, Karlsbakk E, Nylund A, Brevik O, Hansen H. Detection of the myxosporean parasite Parvicapsula pseudobranchicola in Atlantic salmon (Salmo salar L.) using in situ hybridization (ISH). Parasite Vectors. 2015:8:1-6.

Matsukane Y, Sato H, Tanaka S, Kamata Y, Sugita-Konishi Y. Kudoa septempunctata n. sp. (Myxosporea: Multivalvulida) from an aquacultured olive flounder (Paralichthys olivaceus) imported from Korea. Parasitol. Res. 2010;107:865-872.

Maturana CS, Moreno RA, Labra FA, González CA, Rozbaczylo N, Carrasco FD, Poulin E, DNA barcoding of marine polychaetes species of southern Patagonian fjords. Rev. Biol. Mar. Oceanogr. 2011;46:35-42

Miller TL, Adlard RD. Brain infecting kudoids of Australia's coral reefs, including a description of Kudoa lemniscati n. sp (Myxosporea: Kudoidae) from Lutjanus lemniscatus (Perciformes: Lutjanidae) off Ningaloo Reef, Western Australia. Parasitol. Int. 2012;61:333-342

Nehring RB, Thompson KG, Taurman K, Atkinson W. Efficacy of passive sand filtration in reducing exposure of salmonids to the actinospore of Myxobolus cerebralis. Dis. Aquat. Org. 2003:57:77-83.

Ray RA, Holt RA, Bartholomew JL. Relationship between temperature and Ceratomyxa shasta induced mortality in Klamath river salmonids. J. Parasitol. 2012;95:561-569. 
Rangel LF, Santos MJ, Cech G, Székely C. Morphology, Molecular Data, and Development of Zschokkella mugilis (Myxosporea, Bivalvulida) in a polychaete alternate Host, Nereis diversicolor. J. Parasitol. 2009;95:561-569.

Rangel LF, Cech G, Székely C, Santos MJ. A new actinospore type Unicapsulactinomyxon (Myxozoa), infecting the marine polychaete, Diopatra neapolitana (Polychaeta: Onuphidae) in the Aveiro Estuary (Portugal). Parasitology 2011; 138:698-712.

Rangel LF, Rocha S, Castro R, Severino R, Casal G, Azevedo C, Cavaleiro F, Santos MJ. The life cycle of Ortholinea auratae (Myxozoa: Ortholineidae) involves an actinospore of the triactinomyxon morphotype infecting a marine oligochaete. Parasitol. Res. 2015;114: 2671-2678.

Shirakashi S, Morita A, Ishimaru K, Miyashita S. Infection dynamics of Kudoa yasunagai (Myxozoa: Multivalvulida) infecting brain of cultured yellowtail Seriola quinqueradiata in Japan. Dis. Aquat. Org. 2012;101:123-130.

True K, Purcell MK, Foott JS. Development and validation of a quantitative PCR to detect Parvicapsula minibicornis and comparison to histologically ranked infection of juvenile Chinook salmon, Oncorhynchus tshawytscha (Walbaum), from the Klamath River, USA. J. Fish Dis. 2009:32:183-192.

Wolf K, Markiw ME. Biology contravenes taxonomy in the myxozoa: new discoveries show alternation of invertebrate and vertebrate hosts. Science. 1984;225:1449-1452.

Yanagida T, Sameshima M, Nasu H, Yokoyama H, Ogawa K. Temperature effects on the development of Enteromyxum spp. (Myxozoa) in experimentally infected tiger puffer Takifugu rubripes (Temminck \& Schlegel). J. Fish Dis, 2006;29:561-567.

Yokoyama H, Ogawa K, Wakabayashi H. A new collection method of actinosporeans-a probable infective stage of myxosporeans to fishes-from tubificids and experimental infection of goldfish with the actinosporean, Raabeia sp. Fish Pathol. 1991;26:133-138.

Yokoyama H, Whipps CM, Kent ML, Mizuno K, Kawakami H. Kudoa thyrsites from Japanese flounder and Kudoa lateolabracis n. sp. from Chinese sea bass: causative myxozoans of post-mortem myoliquefaction. Fish Pathol. 2004;39: 79-85.

Yokoyama H, Grabner D, Shirakashi S. Transmission biology of the Myxozoa. In: Carvalho ED, David GS, Silva RJ (eds) Health and environment in aquaculture, In Tech, Rijeka, 2012.p. 3-42.

Yokoyama H, Lu M, Mori K, Satoh J, Mekata T, Yoshinaga T. Infection dynamics of Kudoa septempunctata (Myxozoa: Multivalvulida) in hatchery-produced olive flounder Paralichthys olivaceus. Fish Pathol. 2015;50:60-67.

\section{Submit your next manuscript to BioMed Central and we will help you at every step:}

- We accept pre-submission inquiries

- Our selector tool helps you to find the most relevant journal

- We provide round the clock customer support

- Convenient online submission

- Thorough peer review

- Inclusion in PubMed and all major indexing services

- Maximum visibility for your research

Submit your manuscript at www.biomedcentral.com/submit

) Biomed Central 